\title{
In situ immunodetection of activated caspase-3 in apoptotic neurons in the developing nervous system
}

\author{
Anu Srinivasan ${ }^{1,3,4}$, Kevin A. Roth ${ }^{2,4}$, Robert O. Sayers ${ }^{1}$, \\ Kenneth S. Shindler ${ }^{2}$, Angela M. Wong ${ }^{1}$, Lawrence C. Fritz ${ }^{1}$ \\ and Kevin J. Tomaselli, \\ 1 IDUN Pharmaceuticals, Inc., La Jolla, California and \\ 2 Department of Pathology, Washington University School of Medicine, \\ St. Louis, Missouri, USA \\ ${ }^{3}$ corresponding authors: IDUN Pharmaceuticals, Inc. 11085 N. Torrey Pines \\ Road, Suite 300, La Jolla, California 92037, USA, tel: (619) 623-1330; \\ fax: (619) 625-2677; e-mail: anu@idun.com, ktomaselli@idun.com \\ ${ }^{4}$ Contributed equally to this work
}

Received 5.5.98; revised 20.7.98; accepted 10.8.98 Edited by J.C. Reed

\begin{abstract}
Activation of caspase- 3 requires proteolytic processing of the inactive zymogen into $p 18$ and p12 subunits. We generated a rabbit polyclonal antiserum, $\mathrm{CM} 1$, which recognizes the $\mathrm{p} 18$ subunit of cleaved caspase-3 but not the zymogen. CM1 demonstrated an apparent specificity for activated caspase-3 by specifically immunolabeling only apoptotic but not necrotic cortical neurons in vitro. In the embryonic mouse nervous system, CM1 immunoreactivity was detected in neurons undergoing programmed cell death and was markedly increased in Bcl- $\mathrm{x}_{\mathrm{L}}$-deficient embryos and decreased in Bax-deficient embryos. CM1 immunoreactivity was absent in the nervous system of caspase-3-deficient mouse embryos and in neurons cultured from caspase-3-deficient mice. Along with neuronal somata, extensive neuritic staining was seen in apoptotic neurons. These studies indicate that caspase- 3 is activated during apoptosis in the developing nervous system in vivo and that $\mathrm{CM} 1$ is a useful reagent for its in situ detection.
\end{abstract}

Keywords: apoptosis; programmed cell death; neuron; caspase3; immunostaining

Abbreviations: CHAPS: 3-[(3-cholamidopropyl) dimethylammonio]-1-propanesulfonic acid; AcDEVD-amc: $\mathrm{N}$-acetyl-Asp-Glu-ValAsp-7-amino-4-methylcoumarin; HEPES: N-[2-hydroxymethyl] piperazine- $\mathrm{N}^{\prime}$-[2-ethanesulfonic acid]; MTS: (3-(4,5-diethylthiazol2-yl)-5-(3-carboxymethoxyphenyl)-2-(4-sulfophenyl)-2H-tetrazolium, inner salt); PARP: poly ADP-ribose polymerase; TUNEL: terminal deoxynucleotidyl transferase mediated dUTP-nick end labeling

\section{Introduction}

Caspases are cysteine proteases that play an important role in the effector phase of programmed cell death or apoptosis (Cohen, 1997; Henkart, 1996). A growing number of caspases have been identified, of which caspase- 3 appears to play a particularly significant role in mediating neuronal apoptosis. For example, caspase-3 is activated in cultured cortical neurons (Keane et al, 1997) and cerebellar granule neurons (Armstrong et al, 1997) undergoing apoptotic cell death. Moreover, the targeted gene disruption of caspase-3 leads to decreased programmed cell death and results in an expanded ventricular zone, and ectopic and duplicated neuronal structures (Kuida et al, 1996). The marked neuronal phenotype resulting from caspase-3 deficiency indicates an important role for caspase-3 in neuronal programmed cell death. However, direct in situ evidence for caspase-3 activation during neuronal development has not been reported.

Another family of proteins that regulates neuronal apoptosis in response to a wide variety of signals is encoded by the bcl-2 gene family (Farlie et al, 1995; Frankowski et al, 1995; Garcia et al, 1992; GonzalezGarica et al, 1995; Greenlund et al, 1995; Martinou et al, 1994; Shimizu et al, 1995). During nervous system development, $\mathrm{Bcl}-\mathrm{x}_{\mathrm{L}}$, an anti-apoptotic member of the $\mathrm{Bcl}-2$ family, and Bax, a pro-apoptotic member regulate immature neuron survival (Shindler et al, 1997). The targeted gene disruption of $b c l-x$ leads to a massive increase in immature neuron apoptosis while bax deletion potentiates neuron survival (Motoyama et al, 1995; Roth et al, 1996; Deckwerth et al, 1996; Shindler et al, 1997). The increased death of $\mathrm{Bcl}-\mathrm{x}_{\mathrm{L}}$-deficient immature neurons can be prevented both in vivo and in vitro by concomitant Bax deficiency, indicating that these anti-and pro-apoptotic members of the $\mathrm{Bcl}-2$ family are in critical balance (Shindler et al, 1997). While Bcl-2 and Bcl-x overexpression have been shown to inhibit caspase activation (Armstrong et al, 1996; Chinnaiyan et al, 1996; Srinivasan et al, 1996), Bax overexpression has been shown to activate caspases (Xiang et al, 1996). Thus, the effector caspases appear to function downstream of the Bcl-2 family proteins in a final common pathway of apoptosis.

To investigate this proposed pathway of cell death, it would be useful to be able to detect activated caspases in situ. Caspases are expressed in cells as inactive zymogens. Upon induction of apoptosis, the zymogen is activated by proteolytic cleavage at aspartic residues to generate large and small subunits, which together constitute the active enzyme. In the case of caspase-3, the catalytically active form is composed of p18 (amino acids 29-175) and p12 subunits (amino acids 176-277) (Nicholson et al, 1995). Cleavage of synthetic caspase-3 substrates and/or endogenous cellular substrates has been used to indirectly monitor caspase-3 activity in cell and tissue extracts (Cohen, 1997). Similarly, detection of downstream apoptotic cellular events (e.g. nuclear condensation and fragmentation, TUNEL and/or ISEL detection of DNA cleavage, annexin V labeling of surface-associated 
phosphatidylserine) (Cohen, 1997) or antibodies specific for cleaved substrates of caspases, e.g. Fractin (Yang et al, 1998), have been used to indirectly monitor caspase activity in situ.

To directly detect activated caspase-3 at the cellular level, we raised a rabbit polyclonal antiserum, CM1, to a 13 amino acid peptide sequence from the carboxyl terminus of the p18 subunit of caspase-3. Characterization of CM1 indicated that it specifically recognized p18 and not the zymogen form of caspase-3 and that it immunolabeled apoptotic but not normal or necrotic neurons in vitro. Furthermore, Bcl- $\mathrm{x}_{\mathrm{L}}$ deficiency dramatically increased and Bax deficiency decreased neuronal CM1 immunoreactivity in the embryonic mouse nervous system in vivo. In apoptotic neurons, CM1 immunoreactivity was present throughout the cell, including neurites. Finally, in vivo and in vitro studies of caspase-3-deficient neurons demonstrated the specificity of CM1 immunodetection.

\section{Results}

\section{CM1 recognizes the large subunit, $p 18$, of processed caspase- 3 but not unprocessed zymogen}

The reactivity of affinity purified $\mathrm{CM} 1$ to processed, recombinant human and mouse caspase-3 was tested by Western analysis. Twenty ng of enzymatically active human caspase-3 and $200 \mathrm{ng}$ of bacterial lysate containing enzymatically active mouse caspase- 3 were immunoblotted with CM1 (Figure 1a). As expected, CM1 recognized the large (p18) subunit of recombinant human caspase-3 and several species of the large subunit of recombinant mouse caspase-3. The different mouse caspase-3 large subunits are probably derived from differential proteolysis of the $\mathrm{N}$ terminus during expression in E. coli. To determine if $\mathrm{CM} 1$ recognizes the unprocessed zymogen form of caspase-3, lysates from control and anti-Fas treated human Jurkat cells were tested for reactivity with $\mathrm{CM} 1$ or with a commercially available caspase- 3 monoclonal antibody. While the monoclonal antibody clearly recognized the p32 zymogen form of caspase-3 (Figure 1b), CM1 did not. However, CM1 did recognize the large (p18) subunit of processed caspase-3 (Figure 1c). We believe that the caspase-3 large subunit observed in the present study and referred to as p18 is the same CM1 immunoreactive p20 subunit identified in ischemic brain tissue (Namura et al, 1998). In addition, in the apoptotic lysates, CM1 also recognized the induction of a strong p30 band and several weaker bands. The identities of these bands are unclear at present (see Discussion), but the p30 band is not pro-caspase-3 (compare electrophoretic mobilities in Figure $1 b$ and $c$ ). Thus, in extracts of apoptotic cells known to contain activated caspase-3 (Armstrong et al, 1996), CM1 recognized only the processed large subunit $(p 18)$ of caspase-3.

CM1 had similar reactivity in murine cortical neurons. Dissociated E15 mouse cortical neurons were cultured for 2 days and treated with $300 \mu \mathrm{M}$ cytosine- $\beta$-D-arabinofuranoside (AraC) to induce apoptosis. AraC has previously been shown to induce apoptosis in cultured cerebellar granule neurons (Dessi et al, 1995; Ishitani and Chuang, 1996). AraC induced a caspase- 3 like protease activity as evidenced by an increase in the cleavage of the synthetic fluorescent tetrapeptide substrate, AcDEVD-amc (Figure $2 a)$ and by cleavage of the endogenous caspase-3 substrate PARP (Figure 2b). Lysates from neurons treated with AraC for various times were analyzed for caspase-3 processing by Western blotting. To demonstrate the recognition of the processed p18 subunit of caspase-3 by CM1 in neurons, CM1 was compared with a polyclonal antibody (CSP3) against recombinant caspase-3, on immunoblots. The caspase- 3 monoclonal antibody discussed above could not be used since it does not recognize murine caspase-3. In AraC-treated cultures, CSP3 detected decreased p32 zymogen and induction of processed large ( $p 18)$ and small ( $p 12)$ subunits of caspase3 (Figure 3a). In contrast, CM1 recognized neither the unprocessed $\mathrm{p} 32$ or the processed p12 subunit but did immunoreact with the p18 subunit of processed caspase-3 (Figure 3b). The increase in the amount of p18 subunit observed at 4-8 $\mathrm{h}$ corresponded to the initial increase in caspase-3-like enzymatic activity. CM1 also recognized several higher molecular weight bands in apoptotic neuronal lysates, similar to those observed in the Jurkat lysates. Interestingly, the cross-reacting proteins accumulated with similar kinetics as the large p18 caspase-3 subunit. Moreover, while the p42 species was weakly recognized by the CSP3 antibody also, the p30 species was not. Additional comparative immunoblots of AraCtreated neuronal lysates using IEF followed by SDSPAGE with the CSP3 and CM1 antibodies (Figure 3c and d) confirmed that $\mathrm{CM} 1$ recognized the processed large subunit of caspase-3. Thus, in cortical neurons induced to undergo apoptosis in vitro, CM1 recognized the processed large subunit but not the zymogen form of caspase-3.

\section{CM1 specifically immunostains apoptotic neurons in vitro}

Since CM1 preferentially recognized processed caspase-3, we compared its ability to label control and apoptotic neurons immunocytochemically. Control or AraC-treated cortical neurons were fixed and subjected to indirect immunofluorescent staining with CM1 (Figure 4a). Control neurons were not labeled by CM1 (Figure $4 \mathrm{a}$, panel C, open arrows). However, apoptotic neurons in cultures treated for 8 or $24 \mathrm{~h}$ with AraC stained brightly (Figure $4 \mathrm{a}$, panels $\mathrm{F}$ and I, closed arrows). The apoptotic nature of the cells immunostained with CM1 is apparent when the phase contrast image and bisbenzimide stained nuclei are compared with corresponding $\mathrm{CM} 1$ staining (Figure $4 \mathrm{a}$, panels $\mathrm{A}-\mathrm{I}$ ). CM1 brightly stained both the somata and the neurites of apoptotic neurons. Following $8 \mathrm{~h}$ of AraC treatment, neurons could be divided into three classes based on morphology and CM1 immunostaining: (1) cells with normal cellular and nuclear morphology and no CM1 reactivity represented normal cells not yet effected by the AraC-treatment; (2) cells with normal cellular and nuclear morphology but with weak CM1 positivity appeared to represent a population of cells in the early stages of caspase-3 processing and apoptosis (Figure 4a, panel F, 
a

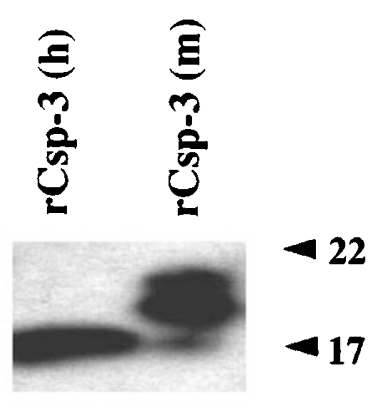

b

\section{$00.512248816 \mathrm{hr}$.}

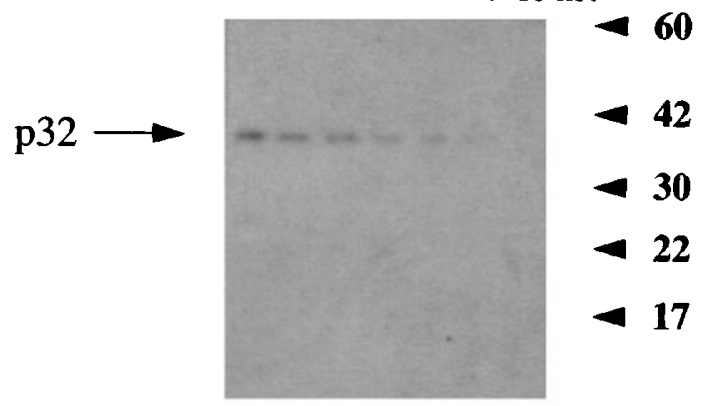

c

$\begin{array}{llllllll}0 & 0.5 & 1 & 2 & 4 & 8 & 16 & h r\end{array}$

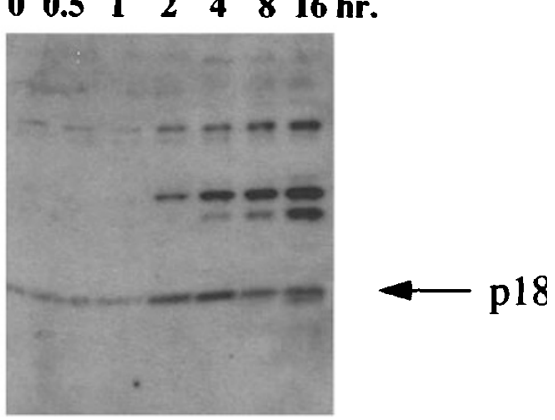

Figure 1 (a) CM1 recognizes the p18 subunit of recombinant mouse and human caspase-3. Twenty ng of recombinant human caspase-3 and 200 ng of bacterial lysate containing recombinant mouse caspase- 3 were analyzed by Western blotting for reactivity to CM1. The arrowheads indicate the protein size markers. (b) Caspase-3 monoclonal antibody (Transduction Labs) recognizes the zymogen form of caspase- 3 but not the processed forms. Twenty-five $\mu$ g each of cell lysates from Jurkat cells treated with anti-Fas for various times were immunoblotted with caspase-3 monoclonal antibody from Transduction Labs. The arrow indicates the unprocessed p32 zymogen form of caspase-3; the arrowheads indicate protein size-markers. (c) CM1 recognizes the processed large subunit of caspase-3 but not the unprocessed zymogen form. Twenty-five $\mu \mathrm{g}$ each of cell lysates from Jurkat cells treated with anti-Fas for various time points were immunoblotted with CM1. The arrow indicates the processed large subunit ( 18 ) of caspase-3; the arrowheads indicate protein size-markers. The identities of the other CM1 cross-reactive bands are not known

open arrowheads) and (3) neurons which exhibited condensed or marginated nuclei and bright CM1 immunolabeling (Figure 4a, panel F, closed arrows) represented cells undergoing apoptosis.

Following $24 \mathrm{~h}$ of AraC treatment, three types of neurons were again found. Some CM1-negative neurons were morphologically normal and thus appeared AraC resistant (Figure 4a, panel I, open arrows). A second group of neurons stained very brightly with $\mathrm{CM} 1$ and possessed fragmented or condensed nuclei representative of apoptotic neurons. Occasional neurons with fragmented or condensed nuclei stained either weakly or not at all with CM1 (Figure 4a, panel I, closed arrowhead). In phase contrast, these cells appeared to be in the extreme late stages of apoptotic disintegration. During this phase, cells may have lost most of the caspase-3 subunit recognized by CM1, and therefore showed weak or no CM1 positivity. CM1 immunolabeling of AraC-treated apoptotic neurons (Figure $4 \mathrm{~b}$, panel B) was completely abolished by a 50 -fold molar excess of CM1 immunogenic peptide but not by a control, unrelated peptide (Figure $4 \mathrm{~b}$, panels $\mathrm{D}$ and $\mathrm{F}$ ), demonstrating that the immunolabeling was antigen specific. Control immunostains with purified rabbit IgG, instead of $\mathrm{CM} 1$, showed no labeling of apoptotic neurons (Figure 4b, panel $\mathrm{H}$ ).

We reported previously that caspase- 3 enzymatic activity was not detectable in cerebellar granule neurons following a necrotic insult (Armstrong et al, 1997). In order to characterize CM1 immunoreactivity in necrotic neurons, cell lysates were generated from a time course of cortical neurons treated with $1 \%$ hydrogen peroxide, harvested at $10 \mathrm{~min}$ intervals up to $60 \mathrm{~min}$. As seen with necrotic cerebellar granule neurons, the necrotic cortical lysates did not show any change in caspase-3 enzymatic activity, as measured by AcDEVD-amc cleavage, even at early time points when the cells were not yet propidium iodide (PI) positive (data not shown). Western blotting of these lysates with $\mathrm{CM} 1$ did not show induction of any $\mathrm{CM} 1$ reactive bands (data not shown). Therefore, to check if CM1 would immunostain necrotic neurons, 2DIV cultures were incubated with medium containing $1 \%$ hydrogen peroxide for $1 \mathrm{~h}$. Cells were labeled with PI prior to fixation to identify both necrotic and apoptotic cells that had lost plasma membrane integrity and become PI permeable. CM1 did not label necrotic neurons (Figure 5, indicated by open arrowheads). However, CM1 immunolabeled only the small 


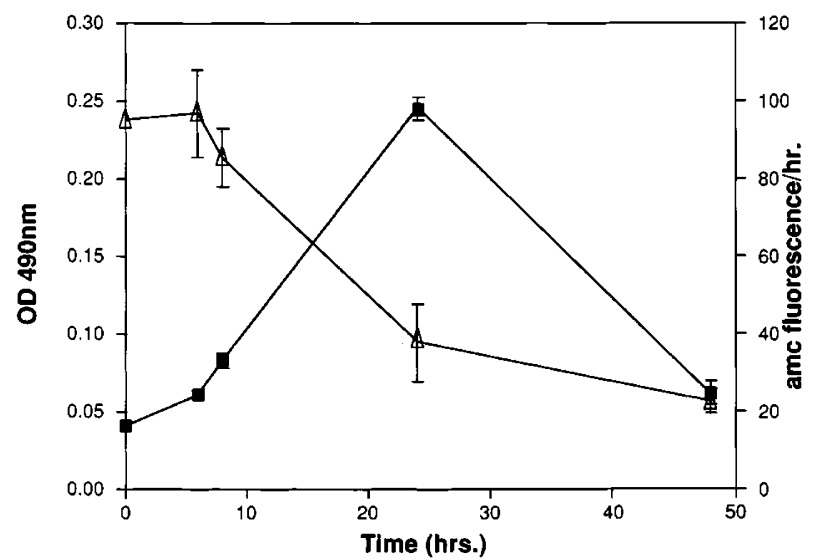

b

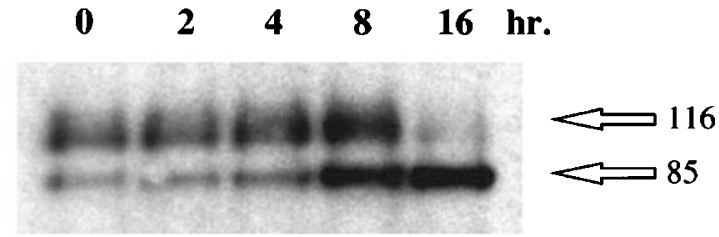

Figure 2 (a) AraC induces apoptosis in 2DIV cortical neurons. Time course of loss of cellular viability measured by loss of MTS conversion (open triangles) and the corresponding increase in cleavage of the fluorogenic substrate for caspase-3-like proteases, Ac-DEVD-amc (closed squares) in neurons treated with $300 \mu \mathrm{M}$ AraC. (b) AraC induces PARP cleavage in 2DIV cortical neurons. Time course of PARP cleavage in neurons treated with $300 \mu \mathrm{M}$ AraC. Open arrows indicate sizes of uncleaved $(116 \mathrm{kD})$ and cleaved (85 kD) PARP

number of neurons in the culture that exhibited apoptotic, fragmented and/or condensed nuclear morphology (Figure 5 , indicated by closed arrows).

\section{CM1 selectively immunolabels apoptotic cells in vivo}

To determine if CM1 labels apoptotic neurons in vivo, tissue sections from embryonic mice were immunostained. During embryonic nervous system development, extensive programmed cell death can be seen in both the dorsal root ganglia and spinal cord. Sections from embryonic day 12-15 (E12-E15) mice were double stained with CM1 to detect activated caspase-3 and either a modified TUNEL protocol (to identifity nuclei with nicked, apoptotic DNA) and/or bisbenzimide to evaluate apoptotic nuclear morphology (condensed, marginated or fragmented). Neurons with apoptotic nuclei were found in the dorsal root ganglia (Figure 6, panel A) and anterior portion of the developing spinal cord (Figure 6, panel D). CM1 immunostaining was readily apparent in these same neuronal structures in the DRG (Figure 6, panels $B$ and $C$ ) and the spinal cord (Figure 6, panels $E$ and $F$ ).

CM1 immunostaining and TUNEL positivity in the spinal cord occasionally co-localized to individual cells; however, cells with either CM1 or TUNEL reactivity alone were common (compare Figure 6, panels D and E with F). Since both CM1 immunostaining and TUNEL detection depend on tissue fixation, processing, and signal amplification protocols employed for their visualization, no attempt to quantitate the percentage of colocalization was made. However, $83 \%$ of $\mathrm{CM} 1$ immunoreactive cells in the embryonic dorsal root ganglia possessed condensed and/ or fragmented bisbenzimide stained nuclei (199 of 240 CM1 immunoreactive cells counted in sections from $11 \mathrm{E} 12-$ E15 mice) indicating that the vast majority of $\mathrm{CM} 1$ immunoreactive neurons were apoptotic. Finally, in both the embryonic dorsal root ganglia and spinal cord, intense CM1 immunolabeling of neuritic processes was observed (Figure 6G). In some cases, the processes could be seen to emanate from $\mathrm{CM} 1$ positive, apoptotic neuronal cell bodies.

The specificity of CM1 immunostaining was tested on sections from embryonic mice homozygous for a caspase-3 targeted gene disruption (Kuida et al, 1996). If CM1 were specific for activated caspase-3, caspase-3-deficient mice should not have CM1 immunohistochemical reactivity. Sections of wild-type and homozygous caspase-3-deficient E14 mice were immunostained with CM1. CM1 immunoreactivity was found in sections of the wild-type mice (Figure $7 A$ ), but was absent in the caspase-3-deficient mouse nervous system, indicating the specificity of CM1 (Figure 7B).

One potential explanation for the ability of $\mathrm{CM} 1$ to specifically immunolabel apoptotic cells is that CM1 might be recognizing some apoptosis-related molecule(s) and not activated caspase- 3 per se. If this were true, $\mathrm{CM} 1$ reactivity may be absent in caspase-3-deficient mice since these mice exhibit decreased neuronal apoptosis. This explanation is unlikely for two reasons. Firstly, the number of TUNEL positive dorsal root ganglia cells in caspase-3deficient E14 embryos decreased only by $54 \pm 13 \%$ (mean \pm S.E.M., $n=5$ ) as compared to wild-type embryos $(n=5)$, indicating that, even in the absence of caspase-3, a significant amount of neuronal programmed cell death is ongoing. None of these apoptotic neurons, identified by TUNEL positivity and/or abnormal nuclear features, were stained by CM1. Secondly, numerous apoptotic cells, as evidenced by TUNEL and/or bisbenzimide staining, were seen outside the nervous system in the caspase-3 deficient embryos; yet the vast majority of these cells lacked CM1 immunoreactivity (Koth, unpublished observations). Taken together, these data show that CM1 specifically labels activated caspase-3 and not some other apoptosis-related molecule(s) and therefore specifically immunolabels caspase-3-dependent apoptotic neurons in vivo.

To further verify the immunocytochemical specificity of CM1, telencephalic cells from caspase $-3^{+/+}(n=9)$, caspase $-3^{+/-}(n=11)$, and caspase $-3^{-1-}(n=4) \mathrm{E} 12-\mathrm{E} 14$ mice were cultured for $48 \mathrm{~h}$ in basal medium containing one per cent fetal calf serum which induces low level apoptosis. Unlike telencephalic cultures from wild-type embryos, (Figure 7C), no CM1 immunoreactive cells were observed in the cultures derived from caspase-3-deficient embryos although apoptotic nuclei were readily observed (Figure 7D). Thus, CM1 appears immunospecific for activated caspase-3 both in vivo and in vitro. 
a

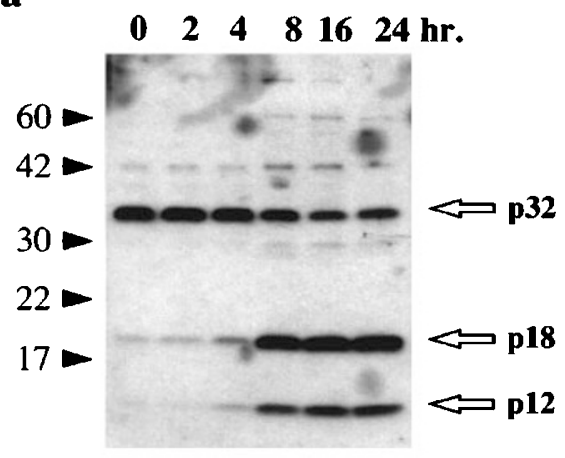

b

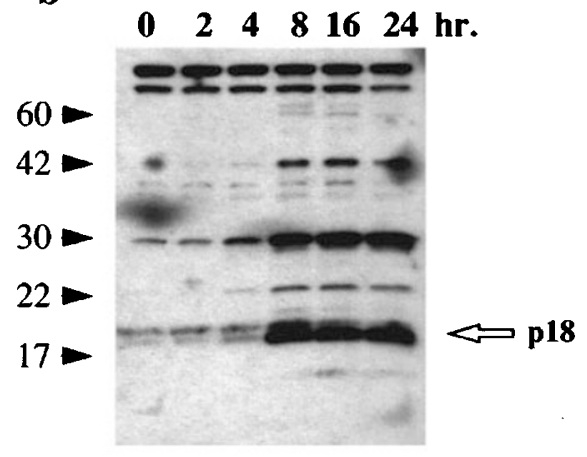

c

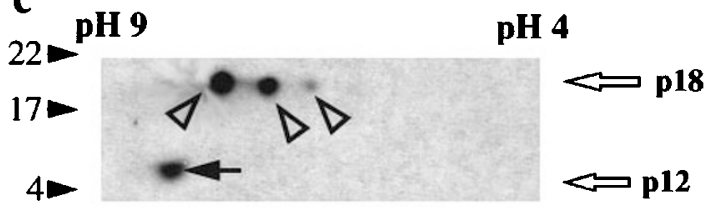

d

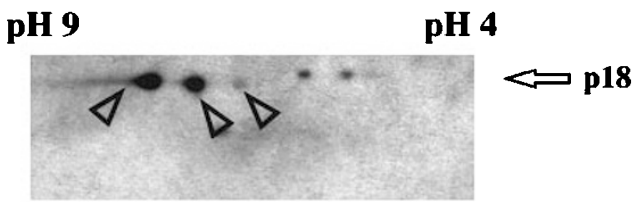

Figure 3 CM1 recognizes the large subunit of processed caspase-3 but not the zymogen. (a,b) Twenty-five $\mu \mathrm{g}$ each of lysates from neurons treated with $300 \mu \mathrm{M}$ AraC for various times were immunoblotted with CSP3 (a) or CM1 (b). Processing of caspase-3 from the p32 zymogen to the processed subunits p18 and p12 was detected using the CSP3 antibody (a). CM1 recognizes induced p18 subunit which co-migrates with the p18 recognized by CSP3, but not the pro-enzyme p32 form or the p12 subunit (b). Open arrows indicate caspase-3 related bands: closed arrowheads indicate migration of protein size markers. (c,d) Two-dimensional immunoblot analysis of a $16 \mathrm{~h}$ apoptotic lysate from neurons treated with $300 \mu \mathrm{M}$ AraC using CSP3 and CM1. Following IEF and SDS-PAGE, the p18 band is found to be comprised of three proteins, all three of which are recognized by both CSP3 and CM1 (open arrowheads). CSP3 also recognizes the p12 species (closed arrow). Open arrows indicate caspase-3 related proteins; closed arrowheads indicate migration of protein size markers

\section{CM1 immunoreactivity parallels neuronal programmed cell death}

To determine if the number of $\mathrm{CM} 1$ immunoreactive cells correlated with the level of programmed cell death of neuronal cells in the developing nervous system, CM1 immunoreactivity was examined in wild-type, $b c l-x^{-1-}, b^{-1-}$, and $b c l-x^{-1-} / b_{a x}{ }^{-1-}$ mice. Bcl- $x_{\mathrm{L}}$-deficient E12 embryos have been reported to show increased apoptosis in immature neurons (Motoyama et al, 1995; Roth et al, 1996). Tissue extracts from $\mathrm{E} 12 \mathrm{bcl}-\mathrm{x}^{-1-}$ brains exhibited significantly higher caspase-3-like proteolytic activity $(260 \pm 29 \%$ $(P<0.05))$ compared with extracts from wild-type $\mathrm{E} 12$ brains, as measured by cleavage of the synthetic tetrapeptide substrate AcDEVD-amc. The increased apoptosis in Bcl$\mathrm{x}_{\mathrm{L}}$-deficient embryos was further evidenced by the intense CM1 immunoreactivity in the anterior horn of the spinal cord and the adjacent dorsal root ganglia in sections from $b c l-x^{-1-}$ E12 embryos (Figure 6H).

In order to compare in vivo levels of CM1 immunolabeling in a defined population of E12 neuronal cells, the number of $\mathrm{CM} 1$ positive cells in the dorsal root ganglia of E12 embryos from wild-type, $b c /-x^{-/-}, b a x^{-1-}$, and $b c l-x^{-1-} / b a x^{-1-}$ mice were quantitated (Table 1). As compared to wild-type mice, the number of CM1 positive cells increased approximately twofold in $b c /-x^{-1-}$ mice. Consistent with the decreased neuronal apoptosis observed in bax $^{-1-}$ mice (Deckwerth et al, 1996; Shindler et al, 1997), CM1 immunolabeling was virtually abolished in dorsal root ganglia of $b a x^{-1-}$ embryos. Bax deficiency has been shown to attenuate the effects of Bcl- $\mathrm{x}_{\mathrm{L}}$ deficiency in vivo and in vitro (Shindler et al, 1997). Consistent with this observation, CM1 immunostaining of double deficient mice showed a normalization of CM1 immunolabeling to wildtype levels. Taken together, these data indicate that caspase-3 activation in vivo parallels levels of programmed cell death in the developing nervous system.

Lastly, to determine if caspase-3 activation also paralleled levels of in vitro neuronal apoptosis in $b c l-x^{-1-}$ cells, primary E12 telencephalic cell cultures were prepared from control and $\mathrm{Bcl}-\mathrm{x}_{\mathrm{L}}$-deficient mice (Table 2). Compared to wild-type cells (Figure $8 \mathrm{~A}$ and $\mathrm{B}$ ), $\mathrm{Bcl}-\mathrm{x}_{\mathrm{L}}$-deficient telencephalic cells grown for $48 \mathrm{~h}$ in basal medium showed an approximately 2.5 -fold increase in apoptotic nuclei (Figure 8C); there was a similar increase in the number of CM1 immunoreactive cells (Figure 8D). These data indicate that caspase- 3 activation closely parallels apoptotic neuronal death in vitro, as well as in vivo.

\section{Discussion}

The important role that caspase-3 plays in regulating programmed cell death in the developing nervous system was previously demonstrated in caspase-3-deficient mice (Kuida et al, 1996). Although there is variability in the observed neuronal phenotype, caspase-3-deficient mice show a marked reduction in apoptosis in the embryonic nervous system, which results in a variety of structural and 

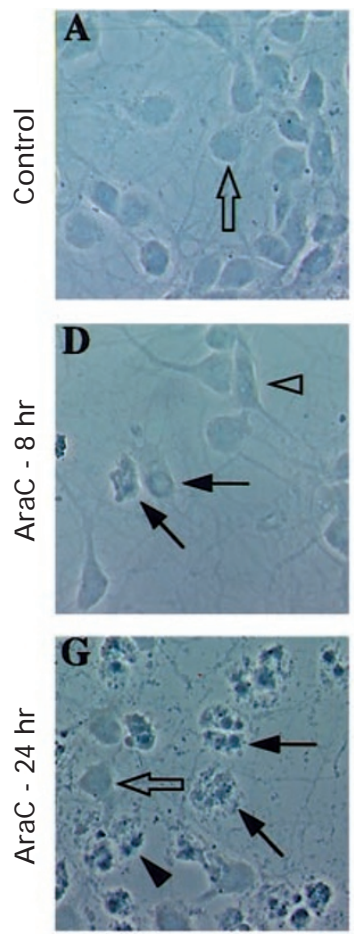

Hoechst
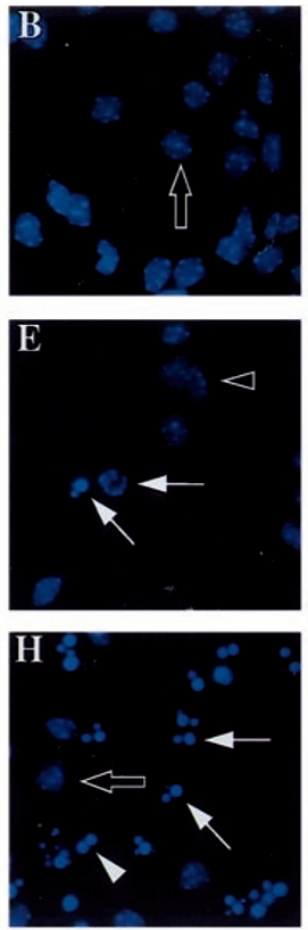

$\mathrm{CM} 1 \mathrm{Ab}$
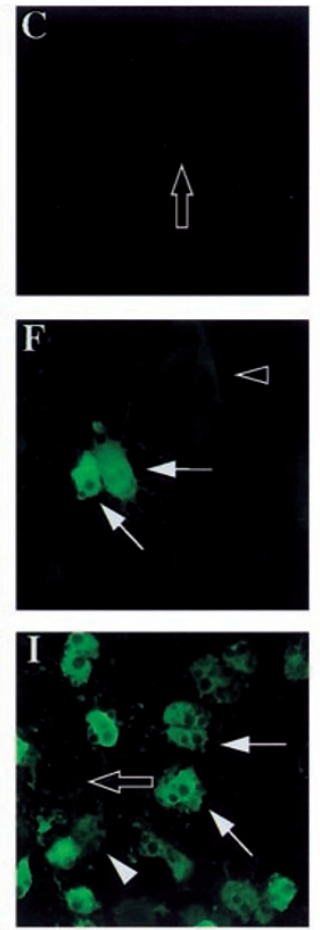

b

Immunogenic peptide+ $\mathrm{CM} 1 \mathrm{Ab}$
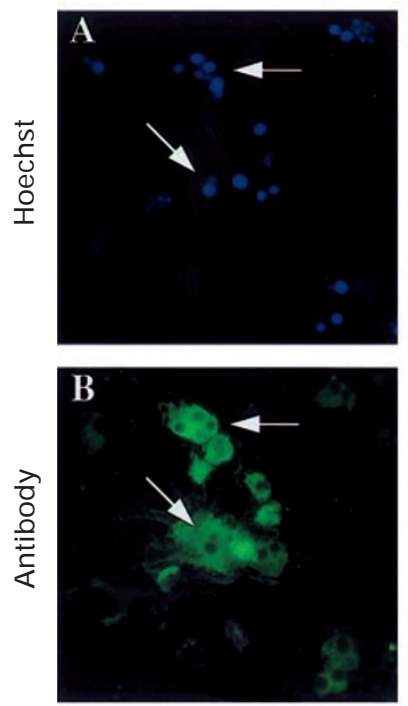
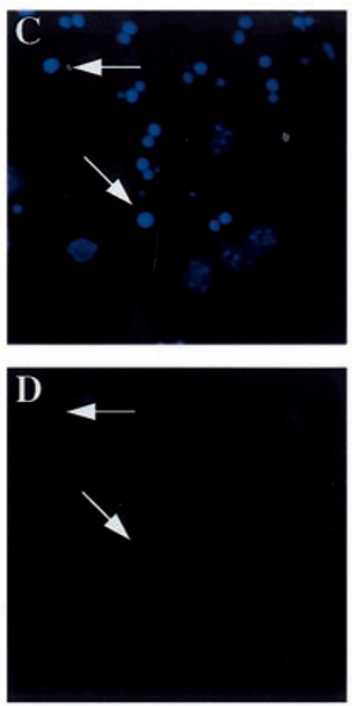

Nonimmunogenic peptide+ $\mathrm{CM} 1 \mathrm{Ab}$
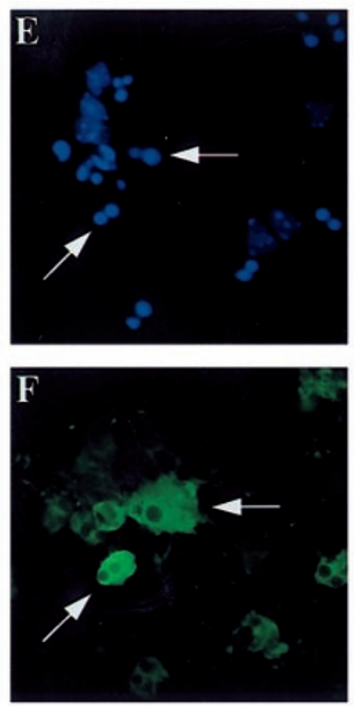

Rabbit IgG
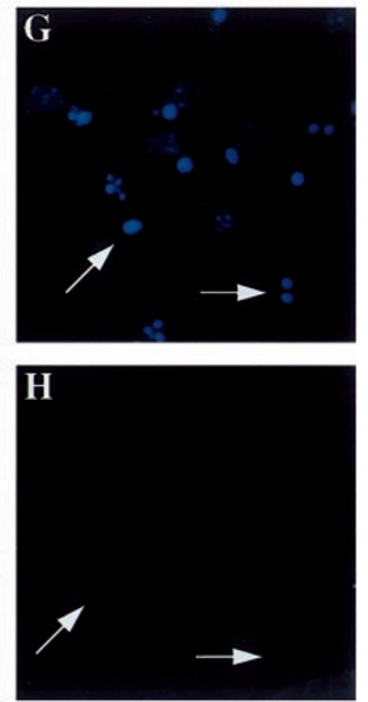

Figure 4 (a) CM1 immunostains apoptotic neurons. Phase contrast and corresponding fluorescence micrographs of control cortical neurons (panels A-C) or neurons treated with $300 \mu \mathrm{M} \mathrm{AraC}$ for 8 (panels D-F) or $24 \mathrm{~h}$ (panels $\mathrm{G}-\mathrm{l}$ ). Open arrows indicate normal cells and nuclei; closed arrows are apoptotic cells and nuclei; open arrowheads identify faintly CM1 immunopositive cells with normal nuclei; closed arrowheads indicate cells with apoptotic nuclei which are negative for CM1. Note that CM1 preferentially immunostains cells which show apoptotic nuclear morphology. (b) CM1 immunostaining of apoptotic neurons is antigen specific. Fluorescence micrographs of cortical neurons treated with $300 \mu \mathrm{M}$ AraC for $16 \mathrm{~h}$. Cells were immunostained with control CM1 antibody (panel B), CM1 preincubated with immunogenic peptide (panel D), CM1 preincubated with irrelevant peptide (panel F) or with rabbit lgG (panel H). All cultures were stained with bisbenzimide to identify apoptotic cells (panels A, C, E and G). Arrows indicate apoptotic neurons. Note: CM1 immunostaining is abolished by the immunogenic peptide only 
Phase contrast

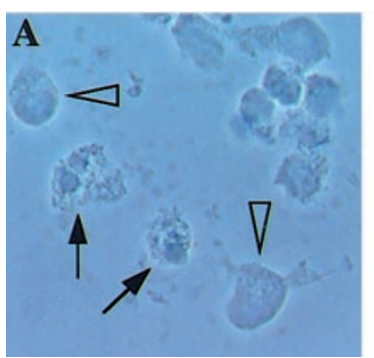

Hoechst

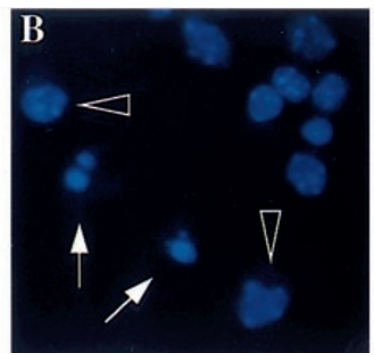

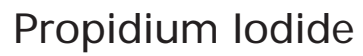

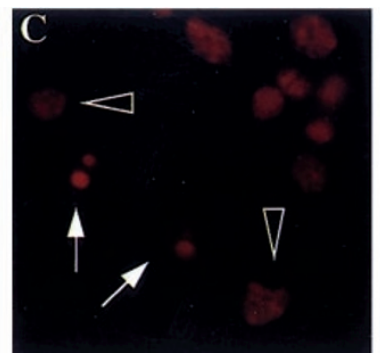

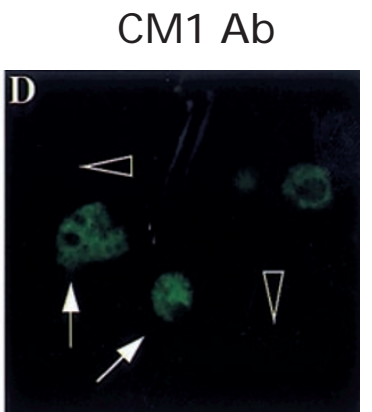

Figure 5 CM1 does not label necrotic cells. Phase contrast and fluorerscence micrographs of 2DIV neurons incubated in media containing $1 \%$ hydrogen peroxide for $1 \mathrm{~h}$. Neurons were incubated with propidium iodide prior to fixation and immunostaining. Note that necrotic cells (open arrowheads) have normal cellular and nuclear morphology. These cells do not stain with CM1. Apoptotic cells exhibit shrunken and fragmented cellular and nuclear morphology (closed arrows) and stain positive with $\mathrm{CM} 1$

histopathological abnormalities in the brain. However, the lack of reagents to specifically identify activated caspase-3 in situ has limited investigations of caspase- 3 activation and its role in experimental and pathological neuronal apoptosis at the cellular level. This study describes the characterization of the CM1 antibody and its application to in situ detection of activated caspase-3.

We have previously shown that $\mathrm{CM} 1$, by virtue of its enzymatic function-blocking activity (Armstrong et al, 1997), can recognize native, enzymatically active caspase-3. In immunoblots of SDS-denatured apoptotic lysates from Fastreated Jurkat cells and AraC-treated cortical neurons, CM1 recognized the large subunit of processed caspase-3 but not the zymogen form of caspase-3. Thus, in cells CM1 appears to be selective for the activated form of caspase-3.

Regarding the specificity of $\mathrm{CM} 1$, in addition to the large subunit of active caspase-3, CM1 also recognized a p30 protein and a few other weaker protein bands that accumulated with kinetics similar to those of the large subunit of caspase-3. This would not be inconsistent with recognition of some other caspases(s), since in most cells multiple caspases become activated during apoptosis (Cohen, 1997). In this regard, CM1 does show weak cross-reactivity to the large subunit of the homologous human protease, caspase-7 (A Srinivasan, unpublished observations). This is not unexpected since 10 of the 13 amino acids in the peptide CM1 immunogen are conserved in caspase-7. However, antibodies to caspase-7 did not detect either caspase-7 or the CM1 cross-reactive proteins in mouse cortical neurons undergoing apoptosis in culture (Srinivasan, unpublished observations). Although recognition by $\mathrm{CM} 1$ of these unidentified cross-reactive proteins may contribute to $\mathrm{CM} 1$ cellular immunostaining, the absence of CM1 staining in apoptotic neurons from the caspase-3-deficient mice, both in vivo and in vitro, clearly demonstrates that the cellular $\mathrm{CM} 1$ reactivity requires expression and activation of caspase-3.

CM1 immunostaining of cortical neurons induced to undergo apoptosis in vitro was largely confined to apoptotic cells. This is consistent with previous reports showing the processing and activation of caspase-3 in cortical neurons following apoptotic signals (Keane et al, 1997). The reported lack of caspase-3 activation following a necrotic insult to cerebellar granule neurons (Armstrong et al, 1997) also appears true of cortical neurons as CM1 failed to label necrotic cortical neurons.

A striking observation was the intense CM1 immunolabeling of apoptotic neuronal processes both in vitro and in vivo. This may not be surprising considering the cytoplasmic distribution of caspase-3 zymogen, the widespread intracellular distribution of mitochondria in neurons, and the important role that cytochrome $c$ efflux from mitochondria appears to play in caspase-3 activation. Recent reports indicate that cytochrome $c$ release into the cytoplasm is an early event in apoptotic signal transduction and can lead to processing and activation of caspase-3 (Yang et al, 1997, Kluck et al, 1997; Li et al, 1997a,b; Bossy-Wetzel et al, 1998). Based on the data presented, it is unclear if neuritic caspase-3 activation can occur independently of the neuronal cell body and whether the neuritic CM1 staining observed in apoptotic cortical neurons, embryonic dorsal root ganglia, and embryonic spinal cord reflects an early or late event in apoptosis. Recent studies have indicated that cleaved forms of endogenous caspase substrates are found in neuritic processes associated with amyloid deposition in Alzheimer's disease (Yang et al, 1998), suggesting that neuritic activation of caspase-3 may play an important role in neurodegenerative disease.

Activated effector caspases have been shown to function downstream of Bcl-2 family proteins (Armstrong et al, 1996; Chinnaiyan et al, 1996; Srinivasan et al, 1996; Xiang et al, 1996). The interplay between the $b c l-2$ and caspase gene families in regulating programmed cell death was readily observed in vivo using $\mathrm{CM} 1$ to monitor activated caspase- 3 in $\mathrm{Bcl}-\mathrm{X}_{\mathrm{L}}$ and Bax-deficient mouse embryos. A marked increase in the number of CM1 immunolabeled neurons was observed in the $b c /-x^{-1-}$ E12 nervous system while the opposite effect was seen in bax $^{-1-}$ embryos. Thus, combined genetic and immunohistochemical evidence indicates that in vivo caspase-3 acts downstream of $\mathrm{Bcl}-\mathrm{x}_{\mathrm{L}}$ and $\mathrm{Bax}$ in regulating neuron survival.

The complex, system- and stimulus-dependent role that caspase-3 plays in regulating apoptosis has recently been shown in caspase-3-deficient embryonic stem cells, mouse 

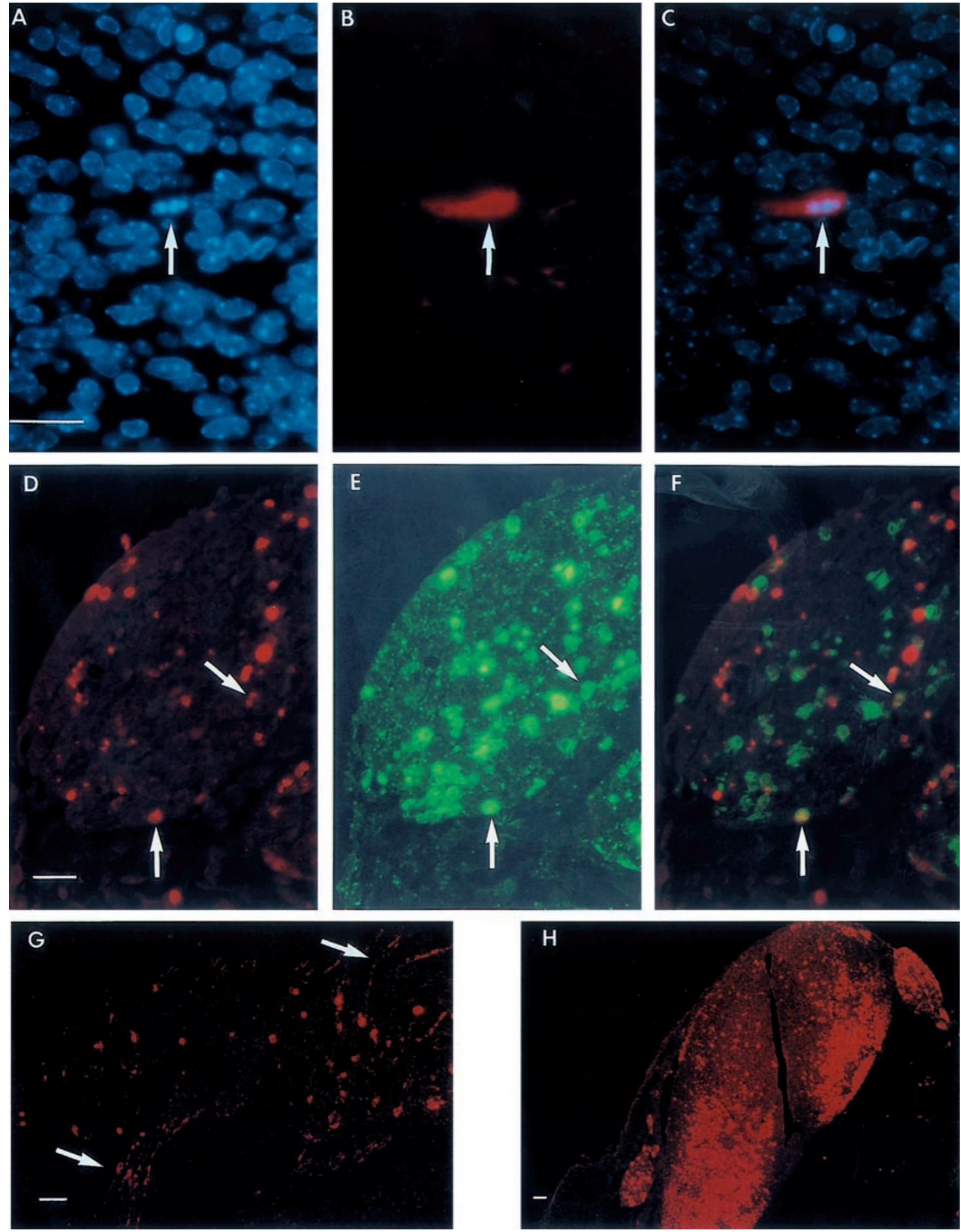

Figure 6 CM1 immunolabels neurons undergoing programmed cell death in vivo. Fluorescence micrographs of E12 spinal cord (A-C) and dorsal root ganglia (D-F). Apoptotic nuclei in the spinal cord were identified by bisbenzimide staining (panel A) and by CM1 immunolabeling (B). Colocalization of CM1 positivity and fragmented nuclear morphology is shown in the dual exposure micrograph (panel C). The dorsal root ganglia were stained using the TUNEL technique (panel D) and CM1 immunolabeling (panel E). Dual exposure micrographs of these two fields (F) shows some co-localization of TUNEL and CM1 positivity. Arrows (panels A-F) indicate cells wherein the CM1 and nuclear stains colocalized. CM1 immunostaining of the E14 dorsal root ganglia (panel G) shows strong reactivity in both the central and peripheral neuritic projections (indicated by arrows). A cross-section from the upper thoracic region of an E12 bcl- $x^{-1-}$ mouse (H) shows nearly confluent CM1 immunoreactivity in the anterior horn of the spinal cord and large numbers of CM1 immunoreactive cells in the adjacent dorsal root ganglia. (Scale bar $=25 \mu \mathrm{m})$ 

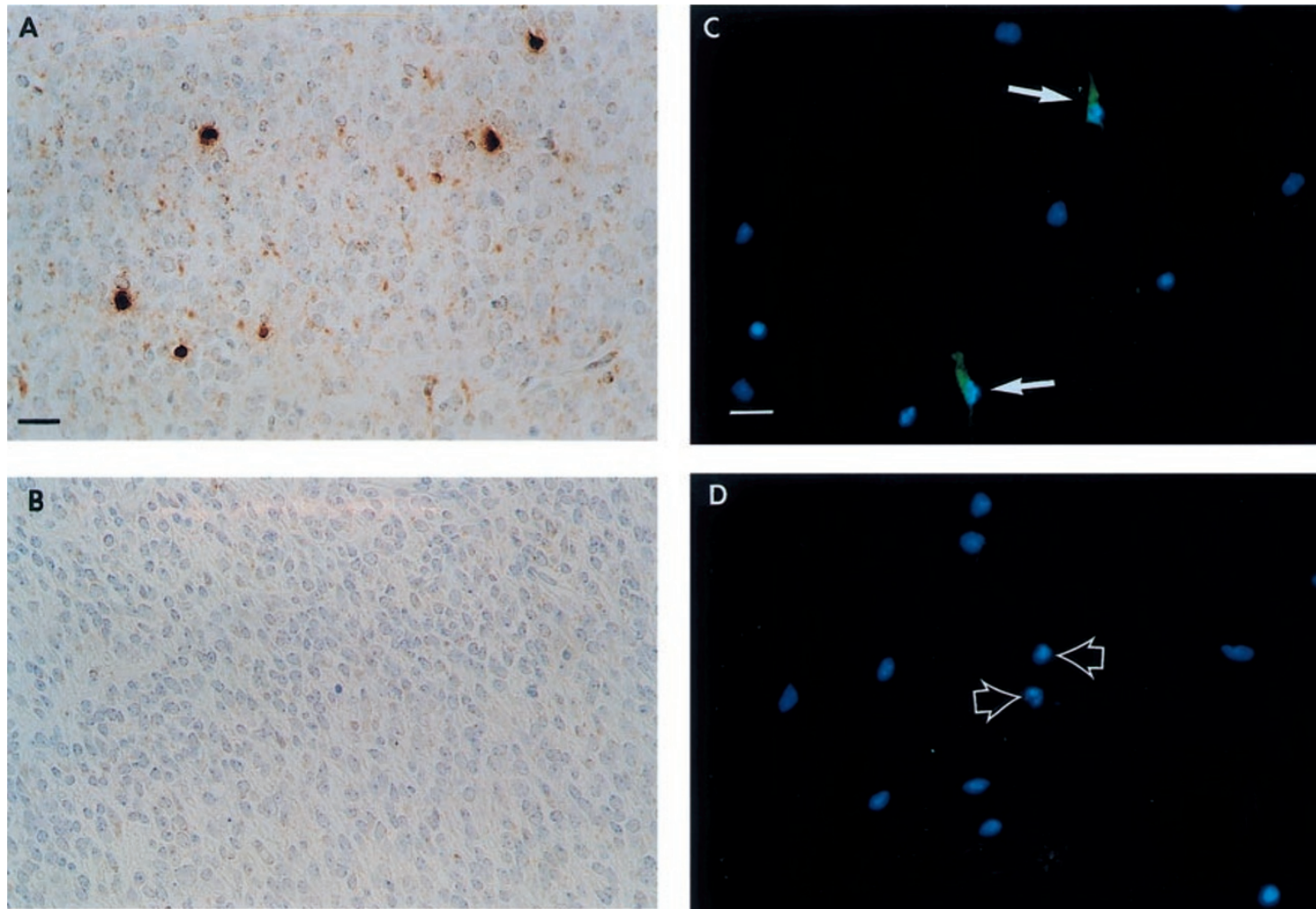

Figure 7 Caspase-3-deficient neurons lack detectable CM1 immunoreactivity. CM1 immunoreactivity is detected in sections of E14 spinal cord from caspase $-3^{+/+}$mice $(\mathbf{A})$ but not in caspase $-3^{-1-}$ littermates (B). Sections were lightly counterstained with the nuclear stain hematoxylin. Dual labeling of E14 telencephalic cell cultures with CM1 (green) and bisbenzimide (blue) shows CM1 immunoreactive cells apoptotic cells in cultures from wild-type embryos (C) but not in identical cultures prepared from caspase-3-deficient embryos (C). Closed arrows indicate apoptotic, CM1 positive neurons; open arrows indicate apoptotic cells lacking CM1 immunoreactivity. (Scale bar $=25 \mu \mathrm{m}$ )

Table 1 CM1 immunoreactivity in E12 DRG

\begin{tabular}{lc}
\hline Genotype & CM1 IR cells/field \\
\hline Wild type & $10.6 \pm 3.1$ \\
bcl-- $x^{-/-}$ & $20.2 \pm 1.8$ \\
bax $^{-/-}$ & $0.6 \pm 0.2$ \\
bcl-x $^{-/-} / \mathrm{bax}^{-1-}$ & $6.2 \pm 2.6$ \\
\hline
\end{tabular}

Sagittal sections of Bouin's fixed, paraffin-embedded E12 mice were immunolabeled with CM1. The number of CM1 immunoreactive (IR) cells per $60 \times$ magnification field of DRG was counted from a minimum of four DRGs per mouse. Three mice of each genotype were analyzed. The mean \pm standard error of the mean for each genotype was calculated. The difference in number of positive cells per field between any two genotypes was significant $(P \leqslant 0.05)$,

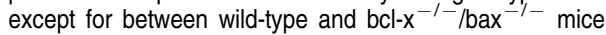

embryonic fibroblasts, and immune cells (Woo et al, 1998). The present studies of the caspase-3-deficient embryonic nervous system indicate that caspase- 3 activation is important for some, but not all, apoptotic neuronal death. For example, although programmed cell death is decreased in the dorsal root ganglia of caspase-3-deficient mice, it is not eliminated. Therefore, additional studies are required to define the importance of caspase-3 activation in defined neuronal cell populations and in neuronal apoptosis triggered by different stimuli (e.g. hypoxia, excitotoxicity).
Table 2 Effect of Bcl- $\mathrm{x}_{\mathrm{L}}$ deficiency on neuronal apoptosis and caspase-3 activation in vitro

\begin{tabular}{lcc}
\hline Genotype & \% Apoptotic & $\%$ CM1 Immunoreactive \\
\hline $\mathrm{bcl}-\mathrm{-}^{+/{ }^{*}}(n=10)$ & $30 \pm 7$ & $27 \pm 6$ \\
$\mathrm{bcl}-\mathrm{x}^{-1-}(n=5)$ & $82 \pm 6 \#$ & $67 \pm 4 \#$ \\
\hline
\end{tabular}

Dissociated $\mathrm{E} 12$ telencephalic cells from $\mathrm{bcl}-\mathrm{x}^{+/+}, \mathrm{bcl}-\mathrm{x}^{+/-}$and $\mathrm{bcl}-\mathrm{x}^{-/}$ embryos grown for $48 \mathrm{~h}$ in unsupplemented basal medium (DMEM) were fixed in $4 \%$ paraformaldehyde and then double labeled with $\mathrm{CM} 1$ and bisbenzimide. Total cells (labeled nuclei), apoptotic nuclei (condensed and/or fragmented morphology), and CM1 immunoreactive cells were counted. Data represent the mean \pm S.E.M. of the percentage of apoptotic and CM1 immunoreactive cells per embryo. Data from $\mathrm{bcl}-\mathrm{x}^{+/+}$and $\mathrm{bcl}-\mathrm{x}^{+/-}$mice were pooled (designated as $b c l-x^{+/ *}$ ) since there were no significant differences between them. \#indicates a significant difference between $\mathrm{bcl}-\mathrm{x}^{-1-}$ culture and corresponding $\mathrm{bcl}-\mathrm{x}^{+/^{*}}$ cultures $(P \leqslant 0.05)$

The data reported here discuss in vivo CM1 immunolabeling of apoptotic neurons during embryonic development. However, we have successfully utilized this antibody to study the activation of caspase- 3 in neuronal apoptosis induced by external stimuli in adult rats. For example, $24 \mathrm{~h}$ post intravenous administration of $1 \mathrm{mg} / \mathrm{kg}$ kainic acid to adult rats, CM1 positive apoptotic neurons and neurites were observed in the pyriform cortex. No CM1 positive neurons or neurites were seen in the cortex of vehicle treated rats. Also, the vast majority of CM1 positive cells had abnormal nuclear 

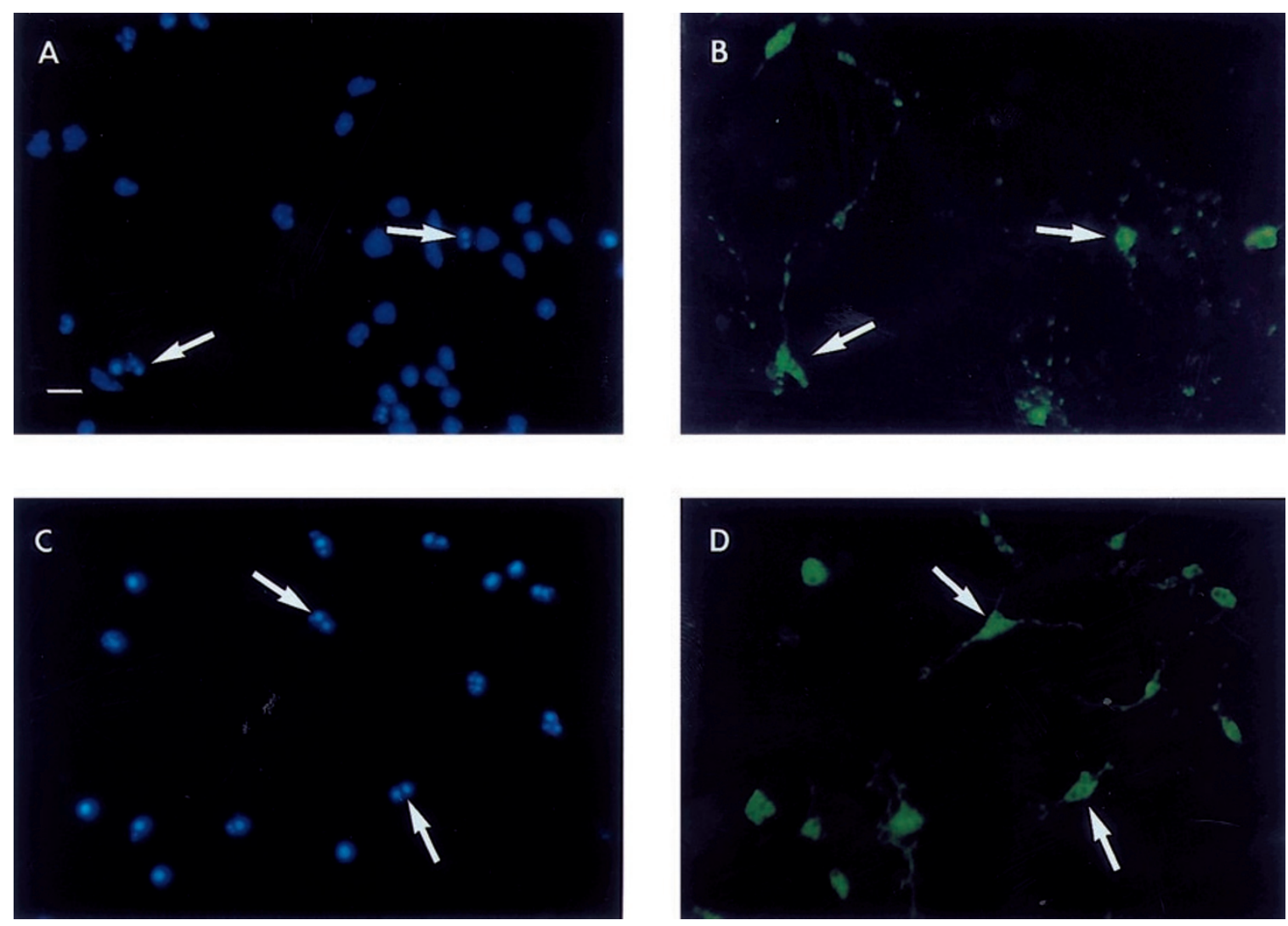

Figure 8 E12 telencephalic cell cultures from $b c l-x^{-1-}$ mice show increased CM1 reactivity. E12 telencephalic cell cultures from wild-type (A and B), or bcl- $x^{-1-}$ mice ( $\mathbf{C}$ and $\mathbf{D})$ were immunolabeled with $\mathrm{CM} 1$ and nuclei were stained with bisbenzimide. Wild-type cultures grown for $48 \mathrm{~h}$ in basal medium show occasional cells with apoptotic nuclear morphology (A) with corresponding CM1 immunoreactivity (B). Bcl- $\mathrm{x}_{\mathrm{L}}$-deficient telencephalic cultures show a marked increase in cells with apoptotic nuclear morphology (C) which are correspondingly CM1 reactive (D). Arrows indicate apoptotic neurons

features characteristic of apoptosis although occasional $\mathrm{CM} 1$ reactive cells with normal appearing nuclei were also found (Srinivasan, unpublished observations). The CM1 antibody has also been used to monitor in situ caspase-3 activation in the brain following transient middle cerebral artery occlusion in adult rats (Namura et al, 1998, and Srinivasan, unpublished observations).

In summary, our data show that CM1 detects activated caspase-3 or a by-product of caspase- 3 activity in neuronal cells undergoing apoptosis. Through the combined use of gene-deficient mice, in vivo and in vitro experimental systems and the CM1 antibody, we have shown that caspase-3 activation occurs during programmed cell death in the developing nervous system. This antibody should prove to be a valuable tool for evaluating the role of caspase-3 activation during development and in specific pathological and trauma conditions at the cellular level.

\section{Materials and Methods}

\section{Animals}

Generation of $\mathrm{Bcl}-\mathrm{X}_{\mathrm{L}}$, Bax, and caspase-3-deficient mice by homologous recombination in embryonic stem cells has been described (Motoyama et al, 1995; Kuida et al, 1996; Shindler et al,
1997). Heterozygous $\left(b c l-x^{+/-}, b x^{+/-}\right.$, or caspase- $\left.3^{+/-}\right)$male and female mice were bred to generate wild-type, heterozygous, and homozygous-deficient embryos, and endogenous and disrupted genes were detected by PCR analysis of tail DNA extracts, as previously described (Shindler et al, 1997).

\section{Reagents}

Unless otherwise indicated, all media, sera and reagents for tissue culture were purchased from Irvine Scientific, Santa Ana, CA, USA and chemicals, enzymes and protease inhibitors were purchased from Sigma, St. Louis, MO, USA.

\section{Cell culture}

Jurkats: Wild-type Jurkats were grown in RPMI 1640 supplemented with $10 \%$ fetal bovine serum (FBS), 200 Units/ml penicillin, and $200 \mu \mathrm{g} / \mathrm{ml}$ streptomycin. Cell density was always maintained at less than $1 \times 10^{6} / \mathrm{ml}$. E15 Cortical neurons: Cortical neurons were isolated from C57BI/6 mouse embryos (Charles River, Boston, MA, USA) harvested at 15 days of gestation. The cortices from the embryos were isolated in Hank's buffered saline solution (HBSS), freed from meninges, and the tissue was dissociated by digestion in $0.1 \%$ trypsin at $37^{\circ} \mathrm{C}$ for $12 \mathrm{~min}$. The trypsin was inactivated by adding basal media containing $10 \% \mathrm{FBS}$ and $0.4 \mathrm{mg} / \mathrm{ml}$ DNAse I, and the tissue was triturated with a $5 \mathrm{ml}$ pipette. Following a 5 min centrifugation at $400 \times g$ at $4^{\circ} \mathrm{C}$, the cells were resuspended in a serum-free formulation 
of Dulbecco's Modified Eagle's Medium (DMEM) supplemented with $2 \mathrm{mM}$ glutamine, $200 \mathrm{Units} / \mathrm{ml}$ penicillin, $200 \mu \mathrm{g} / \mathrm{ml}$ streptomycin, $10 \mathrm{mM}$ HEPES buffer and $1.2 \mathrm{mg} / \mathrm{ml}$ bovine serum albumin at $7.5 \times 10^{5} \mathrm{cells} / \mathrm{ml}$ and plated appropriately in culture plates that were pretreated with polyethylenimine and Minimal Essential Media (MEM) containing 20\% FBS (PEl/serum). All culture plates and dishes used were precoated with $0.05 \%(\mathrm{w} / \mathrm{v}) \mathrm{PEI}$ dissolved in $0.5 \mathrm{M}$ sodium borate overnight at $37^{\circ} \mathrm{C}$. After two washes with phosphate buffered saline (PBS), plates were coated with MEM containing $20 \%$ FBS overnight at $37^{\circ} \mathrm{C}$. Prior to plating the cortical neurons, plates were washed two times with PBS. All further experimentation with the E15 neurons was done following a two-day in vitro (2DIV) culturing at $37^{\circ} \mathrm{C}$ E12 to E14 telencephalic cells: E12 to E14 telencephalic cells were dissociated as previously described (Shindler and Roth, 1996a). Briefly, pregnant mice were sacrificed between gestational day 12 and 14 , embryos removed from the uterus, and separate samples of tail and limb tissue collected from each embryo for DNA extraction. Telencephalic vesicles were isolated, and cells dissociated in a solution of $0.01 \%$ trypsin with $0.004 \%$ EDTA and $0.001 \%$ DNAse I, followed by mild trituration with fire-polished Pasteur pipettes. Dissociated cells were washed and resuspended in basal media [a 1:1 mix of DMEM and Ham's F12 Medium (Life Technologies, Grand Island, NY, USA) with $1.2 \mathrm{~g} / \mathrm{L}$ sodium bicarbonate and $15 \mathrm{mM} \mathrm{HEPES}$, $\mathrm{pH}$ 7.4].

\section{Neuronal viability assay}

E15 Cortical neurons: Neurons were cultured in vitro for two days on PEl/serum coated 96-well culture plates (Costar, Cambridge, MA, USA) at 75000 cells/well and treated with $300 \mu \mathrm{M}$ cytosine- $\beta$-Darabinofuranoside (AraC) for various times. Cells were assayed for viability using the CellTiter Cell Proliferation Assay (Promega, Madison, WI, USA) following manufacturer's instructions. The assay is based upon the reduction of a novel tetrazolium salt, MTS, by respiring cells to a soluble formazan product during a $1 \mathrm{~h}$ incubation at $37^{\circ} \mathrm{C}$. The amount of soluble product generated is monitored by reading absorbance at $490 \mathrm{~nm}$, corrected for the background reduction by media alone. E12-E14 telencephalic neurons: 20000 cells diluted in $150 \mu \mathrm{l}$ of basal media were plated per well on a 48-well tissue culture plate precoated with successive overnight incubations in $0.1 \mathrm{mg} / \mathrm{ml}$ poly-L-lysine and $0.01 \mathrm{mg} / \mathrm{ml}$ laminin (Collaborative Biomedical Products, Bedford, MA, USA). Cultures were incubated in $5 \% \mathrm{CO}_{2}$ at $37^{\circ} \mathrm{C}$ for the indicated times. To measure cell viability, $0.04 \%$ trypan blue solution was added to unfixed cultures and trypan blue positive and negative cells were counted. Approximately 100 to 200 cells were counted from multiple random fields at $40 \times$ magnification.

\section{Caspase-3-enzyme assay}

In vitro: Neurons cultured in PEl/serum coated in 96-well plates at 75000 cells/well were treated with $300 \mu \mathrm{M}$ AraC for various times. Cells were assayed for caspase-3-like enzymatic activity using a protocol previously described (Armstrong et al, 1996). Briefly, following an apoptotic time course, the supernatant medium was carefully aspirated. The cells were lysed by incubation with $50 \mu \mathrm{l}$ of hypotonic buffer (10 mM HEPES, pH 7.4, $42 \mathrm{mM} \mathrm{KCl,} 5 \mathrm{mM} \mathrm{MgCl}$ ) containing protease inhibitors and $0.1 \%$ CHAPS for 10 min (Armstrong et al, 1996). One hundred and forty $\mu \mathrm{l}$ of a buffer containing $20 \mathrm{mM}$ HEPES, pH 7.5, $1 \mathrm{mM}$ EDTA, $5 \mathrm{mM}$ DTT, $10 \%$ sucrose and $0.1 \%$ CHAPS was added to each well. Caspase-3-like activity was assayed by adding $10 \mu \mathrm{l}$ of a $200 \mu \mathrm{M}$ AcDEVD-amc (IDUN, La Jolla, CA) stock to the mixture (final substrate concentration $=10 \mu \mathrm{M}$ ). The generation of the fluorescent aminomethylcoumarin cleavage product was measured on a Cytofluor II fluorerscence plate reader (PerSeptive Biosystems, Farmington, CT; excitation $=360 \mathrm{~nm}$, emission=460 nm). The enzyme activity is represented as change in amc fluorescence per hour. In vivo: Whole brains were isolated from E12 mice, meninges were removed, and brains were placed into $300 \mu \mathrm{l}$ cold lysis solution [20 mM HEPES, $1 \mathrm{mM}$ EDTA, and $250 \mathrm{mM}$ sucrose (HES), pH 7.4, containing $1 \mu \mathrm{g} / \mathrm{ml}$ aprotinin, $1 \mu \mathrm{g} / \mathrm{ml}$ leupeptin, and $1 \mathrm{mM}$ phenylmethylsulfonyl fluoride (PMSF)]. Tissue was triturated on ice using fire-polished Pasteur pipettes. The concentration of protein in each extract was determined by Lowry assay (Lowry et al, 1951) using the Bio-Rad DC Protein Assay (Bio-Rad Laboratories, Hercules, CA) according to the manufacturer's protocol. One hundred $\mu \mathrm{g}$ of each protein sample was diluted into HES solution to a final volume of $135 \mu \mathrm{l}$ in individual wells of a 96-well microtiter plate, and control wells were set up containing HES solution alone. Fifteen $\mu \mathrm{l}$ of a $100 \mu \mathrm{M}$ substrate solution containing Ac-DEVD-amc (Biomol Research Laboratories, Plymouth Meeting, PA) was added to each well (10 $\mu \mathrm{M}$ final concentration). Fluorescent signal was read every 30 min for $1 \mathrm{~h}$ on a Titertek Fluoroskan II fluorescent plate reader (excitation $=355 \mathrm{~nm}$, emission $=460 \mathrm{~nm}$ ). Additional readings were taken. Duplicate wells were set up for each protein extract, and activity was calculated as the change in mean sample fluorescence minus the mean buffer control fluorescence per hour.

\section{Preparation of apoptotic lysates}

To generate apoptotic Jurkat lysates, cells were resuspended at $1 \times 10^{6} / \mathrm{ml}$ and treated with $50 \mathrm{ng} / \mathrm{ml}$ agonist anti-Fas monoclonal antibody (clone $\mathrm{CH}-11$, Pan Vera Labs, Madison, WI). At various times, cells were harvested by centrifuging at $100 \times g$ for $10 \mathrm{~min}$ at $4^{\circ} \mathrm{C}$. To generate apoptotic cortical neuron lysates, 2DIV neurons were incubated at $37^{\circ} \mathrm{C}$ in media containing with $300 \mu \mathrm{M} \mathrm{AraC}$. At various times, cells were harvested by gently scraping with a rubber policeman and pelleted at $700 \times \mathrm{g}$ for $10 \mathrm{~min}$ at $4^{\circ} \mathrm{C}$. Cells $\left(5 \times 10^{6}\right.$ cells/time point for Jurkats and $4.4 \times 10^{6}$ cells/time point for neurons) were resuspended in $50 \mu$ l of lysis buffer ( $50 \mathrm{mM}$ Pipes, $\mathrm{pH} 7.4,50 \mathrm{mM}$ $\mathrm{KCl}, 10 \mathrm{mM}$ EGTA, $2 \mathrm{mM} \mathrm{MgCl} 2,1 \mathrm{mM}$ Dithiothrietol (DTT), $0.1 \mu \mathrm{M}$ PMSF, $1 \mu \mathrm{M}$ Cytochalasin B, $2 \mu \mathrm{g} / \mathrm{ml}$ Leupeptin, $1 \mu \mathrm{g} / \mathrm{ml}$ Pepstatin and $10 \mu \mathrm{g} / \mathrm{ml}$ Aprotinin) and lysed by four successive freeze-thaw cycles at dry ice $/ 37^{\circ} \mathrm{C}$. All cell lysates were centrifuged at $12000 \times g$ at $4^{\circ} \mathrm{C}$ for $10 \mathrm{~min}$ and the clear supernatants were used for Western analysis.

\section{Antibodies}

CPP32 monoclonal antibody: A monoclonal antibody to caspase-3 (clone 19) was purchased from Transduction Laboratories (Lexington, KY). CM1 antibody: Rabbits were immunized with a 13-amino acid peptide corresponding to the C-terminus of the large subunit of human (amino acid residues 163-175) and mouse caspase-3 (CRGTELDCGIETD), conjugated to Keyhole Limpet Hemocyanin. CSP3 antibody: Rabbits were immunized with recombinant, processed caspase-3 prepared as described below. Full length cDNAs for human and mouse caspase-3 were cloned into pET21b (Novagen, Madison, WI), transformed into E. Coli BL 21 (DE3) and expressed as C-terminal 6 -His fusion protein. Bacterial cultures grown in LB/ampicillin at $37^{\circ} \mathrm{C}$ were induced with $1 \mathrm{mM}$ IPTG for $4 \mathrm{~h}$ at $25^{\circ} \mathrm{C}$ and cell pellets were collected by centifugation for $10 \mathrm{~min}$ at $2000 \times \mathrm{g}$ at $4^{\circ} \mathrm{C}$. Bacterial lysates were prepared by sonicating the pellets in $25 \mathrm{mM}$ TRIS, $\mathrm{pH} 7.5,20 \mathrm{mM} \mathrm{NaCl}, 0.1 \%$ Triton X-100, $0.1 \mathrm{mg} / \mathrm{ml}$ lysozyme and centrifuging at $4{ }^{\circ} \mathrm{C}(30000 \times g$ for $40 \mathrm{~min})$. For antibody production, His-tagged human caspase- 3 was purified from bacterial lysate by 
nickel chromatography using a hi-trap column (Pharmacia, Piscataway, $\mathrm{NJ})$ and eluted with an imidazole gradient buffer $(60 \mathrm{mM}-1 \mathrm{M})$. The protein eluted from the column was found to be fully processed to p18 and p12 subunits. Antibody purification: Affinity columns were generated by binding either the free peptide (for CM1) or recombinant caspase-3 (for CSP3) to cross-linked $6 \%$ beaded agarose through sulfhydryl groups (Sulfolink Kit, Pierce, Rockford, IL). Columns were incubated with the appropriate immune serum overnight, followed by sequentially washing with $10 \mathrm{mM}$ TRIS, $\mathrm{pH} 7.4$ and a high salt buffer $(500 \mathrm{mM} \mathrm{NaCl}$ in $10 \mathrm{mM}$ TRIS, pH 7.4). CM1 and CSP3 antibodies were eluted using $100 \mathrm{mM}$ glycine, pH 2.5 (Harlow and Lane, 1988) and buffer exchanged into PBS.

\section{Immunoblotting}

Twenty ng of recombinant human caspase-3, $200 \mathrm{ng}$ of bacterial lysate containing mouse caspase- 3 , and $25 \mu \mathrm{g}$ of cell lysates per lane were resolved by SDS-PAGE on 16\% TRIS/glycine gels (Novex, La Jolla, CA) and transferred to Immobilon PVDF membranes (Millipore, Bedford, MA). For two dimensional electrophoresis, $80 \mu \mathrm{g}$ of the $16 \mathrm{~h}$ AraC treated neuronal lysates were subjected to isoelectric focusing (IEF) overnight at $15^{\circ} \mathrm{C}$ on rehydrated $\mathrm{pH}$ 3-10 Immobiline DryStrips (Pharmacia Biotech, Uppsala, Sweden) using a Multiphor II Electrophoresis system (Pharmacia). Following IEF, the samples were resolved in the second dimension by SDS-PAGE, by placing the IEF strips into the sample compartment of precast $16 \%$ preparative gels (Novex) and then transferred to Immobilon PVDF membranes. For Western blotting, membranes were blocked in PBS/0.1\% Tween (PBST) plus $0.4 \%$ casein (I-block, Tropix, Bedford, MA). Blots were incubated with $0.2 \mu \mathrm{g} / \mathrm{ml}$ primary antibody (anti CPP32 MAb (Transduction Labs, Lexington KY), anti-PARP (Enzyme Systems, Dublin, CA), CM1 or CSP3) diluted in PBST plus casein for $1 \mathrm{~h}$ at room temperature. Following three washes with PBST, blots were incubated with 1:15 000 dilutions in PBST plus casein of alkaline-phosphatase conjugated goat anti-rabbit or anti-mouse IgG (Tropix) for $1 \mathrm{~h}$. Following two washes with PBST, blots were washed twice in assay buffer $\left(10 \mathrm{mM}\right.$ diethanolamine, $\mathrm{pH} 10,1 \mathrm{mM} \mathrm{MgCl}_{2}$ ) and then incubated for $5 \mathrm{~min}$ in $250 \mu \mathrm{M}$ CSPD chemiluminescent substrate (Tropix) in assay buffer. Blots were wrapped in saran wrap and exposed to Biomax film (Kodak, Rochester, NY) overnight.

\section{Immunostaining}

E15 cortical neurons: Neurons were cultured at $2 \times 10^{5}$ cells per chamber on $\mathrm{PEI} /$ serum coated 8-well chamber slides (Becton Dickinson, Franklin Lakes, NJ). After 2 days in culture, cells were treated with either $300 \mu \mathrm{M} \mathrm{AraC}$ for various times $(0-24 \mathrm{~h})$ or with $1 \%$ hydrogen peroxide for $1 \mathrm{~h}$. Cells were fixed by incubating in $10 \%$ formalin in PBS for 20-30 min, washed with PBS and stored at $4^{\circ} \mathrm{C}$ for up to $24 \mathrm{~h}$. Prior to fixation, the hydrogen peroxide treated cultures were labeled with $1 \mu \mathrm{g} / \mathrm{ml}$ propidium iodide (PI) for $30 \mathrm{~min}$ and gently washed four times with cold PBS to remove excess PI. For immunocytochemistry, fixed cells were blocked for $1 \mathrm{~h}$ in PBS containing $10 \%$ normal goat serum (NGS), and $0.4 \%$ Triton X-100. The cells were then incubated at room temperature for $1 \mathrm{~h}$ with $\mathrm{CM} 1$ $(0.2 \mu \mathrm{g} / \mathrm{ml})$ diluted in PBS, containing $2 \%$ NGS and $0.4 \%$ Triton $\mathrm{X}-100$. Following three washes with PBST, cells were incubated for $1 \mathrm{~h}$ with $1 \mu \mathrm{g} / \mathrm{ml}$ Oregon Green conjugated goat anti-rabbit IgG (Molecular Probes, Portland, OR) and $1 \mu \mathrm{g} / \mathrm{ml}$ bisbenzimide (Hoechst 33258, Sigma) in PBS containing $2 \%$ NGS, and $0.4 \%$ Triton X-100. Finally, cells were washed four times with PBST and mounted under citifluor (Ted Pella, Redding, CA) with cover slips. Stained cells were visualized under fluorescence on a Nikon Optiphot microscope and photographed using a Sony CatsEye digital camera. Peptide competition: $0.2 \mu \mathrm{g} / \mathrm{ml}$ of $\mathrm{CM} 1$ antibody was preincubated for $1 \mathrm{~h}$ at room temperature in PBS, $0.2 \%$ NGS, $0.4 \%$ Triton $\mathrm{X}-100$ containing a 50 -fold molar excess of either the immunogenic peptide (CRGTELDCGIETD) or an irrelevant peptide (GQVGRQLAIIGDDDI). Fixed, apoptotic cortical neurons were immunostained with the preincubated CM1 antibody. For the rabbtit IgG control, $0.2 \mu \mathrm{g} / \mathrm{ml}$ purified rabbit IgG (Pharmingen, San Diego, CA) was used instead of the CM1 antibody. Mouse embryos and telencephalic cell cultures (in vivo): Embryonic tissue was obtained, processed, and immunolabeled as previously described (Shindler and Roth, 1996b). Briefly, Bouin's solution (15:5:1 saturated Picric acid:formalin:acetic acid) fixed, paraffinembedded, $4 \mu \mathrm{m}$ thick sections of embryos were used for CM1 immunostaining, TUNEL detection, and multi-label immunohistochemistry. Tyramide signal amplification (TSA) was used to increase the sensitivity of detection over that of conventional techniques. For simultaneous TUNEL and CM1 immunodetection, a modified TUNEL protocol was used as previously described (Tornusciolo et al, 1995). Following deposition of cyanine-3 tyramide (NEN Life Science Products, Boston, MA) to detect TUNEL positive cells, residual peroxidase activity was destroyed by boiling the tissue sections for $1 \mathrm{~min}$ in water. $0.5 \mu \mathrm{g} / \mathrm{ml} \mathrm{CM} 1$ antibody, diluted in PBS-blocking buffer (PBS with $1 \%$ bovine serum albumin, $0.2 \%$ non-fat powdered milk, and $0.3 \%$ Triton $\mathrm{X}-100$ ), was then applied overnight at $4{ }^{\circ} \mathrm{C}$ and detected using fluorescein tyramide. Tissue was counterstained with bisbenzimide (Hoechst 33258) and visualized on a Zeiss-Axioskop microscope equipped with epifluorescence. Telencephalic cell cultures (in vitro): CM1 immunocytochemistry was performed using an antibody concentration of $50 \mathrm{ng} / \mathrm{ml}$ and TSA with fluorescein-conjugated tyramide detection. Cell nuclei were labeled with bisbenzimide as previously described. Numbers of total nuclei, abnormally condensed, fragmented nuclei and $\mathrm{CM} 1$ immunoreactive cells were counted from multiple random fields at $40 \times$ magnification. Approximately 100 to 200 cells were counted per well. Significance was established using oneway ANOVA for cell counts or Kruskal-Wallis ANOVA on percentages of apoptotic or CM1 immunoreactive cells.

\section{Acknowledgements}

Caspase-3 deficient mice were generously provided by Drs. Pasko Rakic and Richard Flavell (Yale University). We gratefully acknowledge Drs. Robert Armstrong and Thomas Deckwerth for scientific discussions. We also thank Cecelia Latham and Jacquie McDonough for expert technical assistance and Angela Schroeder for secretarial support. This work was supported in part by NIH grants NS35107 and NS35484.

\section{References}

Armstrong RC, Aja T, Xiang J, Gaur S, Krebs JF, Hoang K, Bai X, Korsmeyer SJ, Karanewsky DS, Fritz LC and Tomaselli KJ (1996) Fas-induced activation of the cell death-related protease CPP32 is inhibited by Bcl-2 and by ICE family protease inhibitors. J. Biol. Chem. 271: 16850-16855

Armstrong RC, Aja TJ, Hoang KD, Gaur S, Bai X, Alnemri ES, Litwack G, Karanewsky DS, Fritz LC and Tomaselli KJ (1997) Activation of the CED3/ICE-related protease CPP32 in cerebellar granule neurons undergoing apoptosis but not necrosis. J. Neurosci. 17: 553-562

Bossy-Wetzel E, Newmeyer DD and Green D (1998) Mitochondrial cytochrome c release in apoptosis occurs upstream of DEVD-specific caspase activation and independently of mitochondrial transmembrane depolarization. EMBO J. 17: $37-49$

Chinnaiyan AM, Orth K, O'Rourke K, Duan H, Poirier GG and Dixit VM (1996) Molecular ordering of the cell death pathway. J. Biol. Chem. 271: 4573-4576 
Cohen GM (1997) Casapses: the executioners of apoptosis. Biochem. 326: 1- 16

Deckwerth TL, ElliottJL, Knudson CM, Johnson JrEM, Snider WD and Korsmeyer S (1996) BAX is required for neuronal death after trophic factor deprivation and during development. Neuron 17: 401-411

Dessi F, Pollard H, Moreau J, Ben-Ari Y, Charriaut-Marlangue C (1995) Cytosine arabinoside induces apoptosis in cerebellar neurons in culture. J. Neurochem. 64: $1980-1987$

Farlie PG, Dringen R, Rees SM, Kannourakis G and Bernard O (1995) bcl-2 transgene expression can protect neurons against developmental and induced cell death. Proc. Natl. Acad. Sci. USA. 92: 4397-4401

Frankowski H, Missotten M, Fernandez P-A, Martinou I, Michel P, Sadoul R and Martinou J-C (1995) Function and expression of the Bcl-xgene in the developing and adult nervous system. NeuroReport 6: 1917-1921

Garcia I, Martinou I, Tsujimoto Y and Martinou J-C (1992) Prevention of programmed cell death of sympathetic neurons by the bcl-2 proto-oncogene. Science 258 302-304

Gonzalez-Garcia M, Garcia I, Ding L, O'Shea S, Boise LH, Thompson CB and Nunez $\mathrm{G}$ (1995) $b c /-x$ is expressed in embryonic and postnatal neural tissues and functions to prevent neuronal cell death. Proc. Natl. Acad. Sci. USA. 92: $4304-$ 4308

Greenlund LJS, Korsmeyer SJ and Johnson Jr EM (1995) Role of BCL-2 in the survival and function of developing and mature sympathetic neurons. Neuron 15: $649-661$

Harlow E and Lane D (1988) Antibodies: a laboratory manual, pp 285-317, Cold Spring Harbor Laboratory, Cold Spring Harbor, New York

Henkart PA (1996) ICE family proteases: mediators of all apoptotic cell death? Immunity 4: 195-201

Ishitani R and Chuang D-M (1996) Glyceraldehyde-3-phosphate dehydrogenase antisense oligodeoxynucleotides protect against cytosine arabinonucleosideinduced apoptosis in cultured cerebellar neurons. Proc. Natl. Acad. Aci. 93 9937-9941

Keane RW, Srinivasan A, Foster LM, Testa M-P, Ord T, Nonner D, Wang H-G, Reed JC, Bredesen DE and Kayalar C (1997) Activation of CPP32 during apoptosis of neurons and astrocytes. J. Neuroscience Res. 48: 168-180

Kluck RM, Bossy-Wetzel E, Green D and Newmeyer DD (1997) The release of cytochrome c from mitochondria: a primary site for $\mathrm{Bcl}-2$ regulation of apoptosis. Science 275: 1132-1136

Kuida K, Zheng TS, Na S, Kuan C-Y, Yang D, Karasuyama H, Rakic P and Flavell RA (1996) Decreased apoptosis in the brain and premature lethality in CPP32deficient mice. Nature 384: 368-372

Li F, Srinivasan A, Wang Y, Armstrong RC, Tomaselli KJ and Fritz LC (1997a) Cellspecific induction of apoptosis by microinjection of cytochrome c. J. Biol. Chem. 272: $30299-30305$

Li P, Nijhawan D, Budihardjo I, Srinivasula SM, Ahmad M, Alnemri ES and Wang X (1997b) Cytochrome $c$ and dATP-dependent formation of Apaf-1/caspase-9 complex initiates an apoptotic protease cascade. Cell 91: 479-489

Lowry OH, Rosebrough NJ, Farr AL and Randall RJ(1951)Protein measurement with the folin phenol reagent. J. Biol. Chem. 193: 265-275

Martinou J-C, Dubois-Dauphin M, Staple JK, Rodriguez I, Frankowski H, Missotten M, Albertini P, Talabot D, Catsicas S, Pietra C and Huarte J (1994) Overexpression of $\mathrm{Bcl}-2$ in transgenic mice protects neurons from naturally occurring cell death and experimental ischemia. Neuron 13: 1017-1030
Motoyama N, Wang F, Roth KA, Sawa H, Nakayama K-I, Nakayama K, Negishi I, Senju S, Zhang Q, Fuji S and Loh DY (1995) Massive cell death of immature hematopoietic cells and neurons in Bcl-x-deficient mice. Science 267: 15061510

Namura S, Zhu Jinmin, Fink K, Endres M, Srinivasan A, Tomaselli K, yuan J and Moskowitz MA (1988) Activation and cleavage of caspase-3 in apoptosis induced by experimental cerebral ischemia. J. Neurosci. in press

Nicholson DW, Ali A, Thornberry NA, Vaillancourt JP, Ding CK, Gallant M, Gareau Y, Griffin PR, Labelle M, Lazebnik YA, Munday NA, Raju SM, Smulson ME, Yamin T, Yu VL and MillerDK (1995) Identification and inhibition of the ICE/Ced-3 protease necessary for mammalian apoptosis. Science 376: 37-43

Roth KA, Motoyama N and Loh DY (1996) Apoptosis of $b c l-x$-deficient telencephalic cells in vitro. J. Neurosci. 16: 1753-1758

Shimizu S, Eguchi Y, Kosaka H, Kamiike W, Matsuda H and Tsujimoto Y (1995) Prevention of hypoxia-induced cell death by Bcl-2 and Bcl-xL. Nature 374:811 813

Shindler KS, Latham CB and Roth KA (1997) bax deficiency prevents the increased cell death of immature neurons in $b c l-x$-deficient mice. J. Neurosci. 17: $3112-$ 3119

Shindler KS and Roth KA (1996a) Cholera toxin binds to differentiating neurons in the developing murine basal ganglia. Dev. Brain Res. 92: 199-210

Shindler KS and Roth KA (1996b) Double immunofluorescent staining using two unconjugated primary antisera raised in the same species. J. Histochem. Cytochem. 44: $1331-1335$

Srinivasan A, Foster LM, Testa M-P, Ord T, Keane RW, Bredesen DE, Kayalar C (1996) Bcl-2 expression in neural cell blocks activation of ICE/CED-3 family proteases during apoptosis. J. Neurosci. 16: $5654-5660$

Tornusciolo DRZ, Schmidt RE and Roth KA (1995) Simultaneous detection of TDTmediated dUTP-biotin nick end labeling (TUNEL)-positive cells and multiple immunohistochemical markers in single tissue sections. BioTechniques 19: $800-805$

Woo M, Hakem R, Soengas MS, Duncan GS, Shahinian A, Kägi D, Hakem A, McCurrach M, Khoo W, Kaufman SA, Senaldi G, Howard T, Lowe SW and Mak WM (1998) Essential contribution of caspase 3/CPP32 to apoptosis and its associated nuclear changes. Genes Develop. 12: 806-819

Xiang J, Chao DT and Korsmeyer SJ (1996) Bax-induced cell death may not require interleukin $1 \beta$-converting enzyme-like proteases. Proc. Natl. Acad. Sci. USA. 93 : $14559-14563$

Yang F, Sun X, Beech W, Teter B, Wu S, Sigel J, Vinters HV, Frautschy SA and Cole GM (1998) Antibody to caspase-cleaved actin detects apoptosis in differentiated neuroblastoma and plaque-associated neurons and microglia in Alzheimer's disease. Am. J. Pathol. 152: 379-389

Yang J, Liu X, Bhalla K, Kim CN, Ibrado AM, Cai J, Peng T-I, Jones DP and Wang X (1997) Prevention of apoptosis by Bcl-2: release of cytochrome $\mathrm{C}$ from mitochondria blocked. Science 275: $1129-1132$ 